\title{
The major factors associated with increased dog population vis-a-vis spread of rabies within Srinagar district of Kashmir Valley, India"
}

\author{
Namera Thahaby ${ }^{1}$, Afzal Akand ${ }^{2}$, Abdul Bhat ${ }^{2}$, and Shabeer Hamdani² \\ ${ }^{1} \mathrm{SKUAST}$ FVSc and AH \\ ${ }^{2}$ Affiliation not available
}

September 11, 2020

\begin{abstract}
INTRODUCTION: Information regarding open garbage dumps may cause public health dilemma within the community and cause stray dog proliferation. Most wastes have a family origin and stray dogs are largely attracted by possible wastes from cookery or former foods. The information, besides as attitudes and perception on rabies, is thus vital for the prevention of human deaths. Information regarding major factors associated with increased dog population can spot awareness gaps which can influence bar practices plus lead to needless deaths. METHODS: Two sources i.e. primary and secondary sources were utilized for identifying the probable factors responsible for increased dog population. These factors primarily included garbage management, specific control measures for dog population by stakeholders and perception of people. The secondary source includes Srinagar Municipal Corporation, for collecting the relevant information RESULTS: Regarding the major factors associated with increases dog population, the respondents (both the people $99.68 \%$ and commercial $100 \%$ ) believed that open garbage dumps are a public health barrier in the area and commence to stray dog proliferation. Also combined rabies control measures coupling dog population control, removal of dog free-roaming and proliferation must be fulfilled. Till date around 2,000 sterilizations were conducted and also around 2,000 stray dogs were administered the anti-rabies vaccine. CONCLUSION: Open garbage dumps are a public health obstacle in the Srinagar area and they commence to stray dogs proliferation. Till date only around 2,000 sterilizations were conducted and also around 2,000 stray dogs were administered the anti-rabies vaccine, however, this is too less in comparison with the total population of dogs and still, the ballot of dogs from the particular zones of Srinagar is deficient.
\end{abstract}

\section{TITLE PAGE}

Title of the article: "The major factors associated with increased dog population vis-a-vis spread of rabies within Srinagar district of Kashmir Valley, India"

Running title: Factors associated with increased dog population vis-a-vis spread of rabies

1. Dr.Namera Thahaby ${ }^{1}$, PhD Scholar, Division of Veterinary and Animal Husbandry Extension, FVSc \& AH, SKUAST-Kashmir, Srinagar, J \& K, India

2. Dr. Afzal Hoque Akand ${ }^{2}$, Assistant Professor, Division of Veterinary and Animal Husbandry Extension, FVSc \& AH, SKUAST-Kashmir, Srinagar, J \& K, India

3. Dr.Abdul Hai Bhat ${ }^{3}$, Professor \& Head. Division of Veterinary and Animal Husbandry Extension, FVSc \& AH, SKUAST-Kashmir, Srinagar, J \& K, India

4. Dr. Shabeer Ahmed Hamdani ${ }^{4}$, Assistant Professor, Division of Veterinary and Animal Husbandry Extension, FVSc \& AH, SKUAST-Kashmir, Srinagar, J \& K, India 
Corresponding Author:

Name: Dr.Namera Thahaby

Address: PhD Scholar, Division of Veterinary and Animal Husbandry Extension, FVSc \& AH, SKUASTKashmir, Srinagar, J \& K, India

Phone numbers: 7006570307

E-mail address:nimrazahbi@gmail.com

"The major factors associated with increased dog population vis-a-vis spread of rabies within Srinagar district of Kashmir Valley, India"

\section{Summary}

Information regarding open garbage dumps may cause public health dilemma within the community and cause stray dog proliferation. Most wastes have a family origin and stray dogs are largely attracted by possible wastes from cookery or former foods. The information, besides as attitudes and perception on rabies, is thus vital for the prevention of human deaths. Information regarding major factors associated with increased dog population can spot awareness gaps which can influence bar practices plus lead to needless deaths. Two sources i.e. primary and secondary sources were utilized for identifying the probable factors responsible for increased dog population. These factors primarily included garbage management, specific control measures for dog population by stakeholders and perception of people. The secondary source includes Srinagar Municipal Corporation, for collecting the relevant information. Regarding the major factors associated with increases dog population, the respondents (both the people $99.68 \%$ and commercial 100\%) believed that open garbage dumps are a public health barrier in the area and commence to stray dog proliferation. Also combined rabies control measures coupling dog population control, removal of dog free-roaming and proliferation must be fulfilled. Till date around 2,000 sterilizations were conducted and also around 2,000 stray dogs were administered the anti-rabies vaccine. Open garbage dumps are a public health obstacle in the Srinagar area and they commence to stray dogs proliferation. Till date only around 2,000 sterilizations were conducted and also around 2,000 stray dogs were administered the anti-rabies vaccine, however this is too less in comparison with the total population of dogs and still, the ballot of dogs from the particular zones of Srinagar is deficient.

Key words: Dog population, Major factors, Rabies, Srinagar

\section{INTRODUCTION}

Despite being utterly avertable, canine rabies affects 80, 00,000 people/year in India. Even if rabies represents a big threat to public health, few studies examine the relation of accelerating garbage dumps, stray dog population, and perception of individuals concerning their role within the exploit and unfold of rabies. Information regarding open garbage dumps (OGDs) may cause a public health dilemma within the community and cause stray dog proliferation (Raymond et al., 2015). Most wastes have a family origin and stray dogs are largely attracted by possible wastes from cookery or former foods. The information, besides as attitudes and perception on rabies, is thus vital for the prevention of human deaths and management in animals (Abedi et al., 2017). The majority, of the people, typically have low information on rabies which must be tackled through stakeholders (Sambo et al., 2014).

A newly applied canine registration has discovered 91,000 dog populaces in Srinagar town alone (Lone et al., 2014). On the off chance that we will in general contrast this and the human populace, it makes one canine for every twelve low classes. The statistics data of dog populace from elective regions don't appear to be possible. Be that as it may, in a shocking disclosure on hound danger in the geographic district, at least eighty people have passed on of rabies inside the previous five years through 80,000 dog chomps are accounted for in the valley (The Greater Kashmir, 2013). Kashmir valley had observed $26932 \operatorname{dog}$ bites during 2017 out of those 9514 cases were as of Srinagar (Ain et al., 2018). Canine chomps in the Kashmir district are fundamental albeit invigorating model for tending to overall inquiries that emerge regarding the 
significant and saw the danger. For what reason are these issues emerging with increased recurrence? How we ought to oversee and control them? In this way, the Kashmir area includes a colossal test to battle with such rising/reappearing Zoonotic ailment for sparing a tremendous human populace that is regularly a greater risk. The region was picked definitively because it is thickly colonized with canine populace most likely because of a botch of trash. The rising road hound populace is driving heightening fear in the city. Inside the Srinagar Shri Maharaja Hari Singh medical clinic, the injuries frequently dark the idea of assault the individuals face in the city.

\section{RESEARCH METHODOLOGY}

A survey was carried out in Srinagar district to consider the people's understanding and outlets exercise on rabies and the position of open garbage dumps in the transmission of this disease. Two sources i.e. primary and secondary sources were utilized for identifying the probable factors responsible for increased dog population. These factors primarily included garbage management, specific control measures for dog population by stakeholders and perception of people. The secondary source includes Srinagar Municipal Corporation, for collecting the relevant information. As per Srinagar Municipal Corporation (SMC), the city is divided into two divisions, four zones and 34 administrative wards (Table 1). The four administrative zones are North, South, East, and West. To maximize the diversity of population response, all the four zones were considered for the present investigation. The wards that were selected were shown in the (Table 1) with yellow colour. From each randomly selected ward, 20 households were selected as respondents for data collection (accidental sampling). Thus a total of 320 respondents were taken. In addition, 3 commercial respondents from each of selected ward (i.e. 4 wards from each of zone) were asked for their opinion on the subject making a total number of respondents to be 48. The questionnaire designed for this study consisted of closed and a few open-ended questions. It had four parts: waste characteristics and disposal pattern, availing the service, risk factors of rabies transmission, and waste management. These questions had been asked to common person and retailers.

\section{RESULTS}

The results are being presented under following sub heads:

- Srinagar Municipal Corporation

- Peoples' perception

\section{SRINAGAR MUNICIPAL CORPORATION}

The municipal body of Srinagar is the Srinagar Municipal Corporation. The SMC is liable for running the civic facilities in the city. Key errands of SMC are to offer water supply services, underground drainage services, sanitation services, solid waste management, development and maintenance of roads, street lights and other required civic facilities to the people staying within municipal boundaries of the city. The commissioner is the chief executive of the municipal corporation. The managerial power of the SMC is vested amid the municipal commissioner and joint commissioners chosen by the government of Jammu and Kashmir.SMC has diverse departments for the effectual running and administration of the functionaries.

\section{Milieu of waste}

The city witness drastic changes in temperature during winter and summers. As a result, the waste generation quantity in the city is not uniform throughout the year. The winters in the city are severe and the mean temperatures during winters are in a range of sub $5^{\circ} \mathrm{C}$. Due to the severe cold, the commercial activities of the city come down drastically. As a result of which the waste quantity generation from commercial establishments and other related waste generators reduces. During the summer, the temperature becomes normal and increases $16^{\circ} \mathrm{C}$ to $29^{\circ} \mathrm{C}$. In the summer increased tourism activities result in increased floating population and increased commercial activities. In summers, most of the hotels and other tourism-related institutions experience full occupancy. As a result of which the quantity of waste generated in the city increases. 
The primary collection of waste in the city is conducted by a combination of the door to door collection, street sweeping and by collecting the waste disposed of in open locations. The waste from door to door collection is collected using hand carts, wheelbarrows, and Hopper Vehicles. The streets of old city areas are very narrow. The door to door collection, street sweeping and drain cleaning is conducted together in these narrow streets using hand carts and wheelbarrows. There are about 1200 Hand Carts and 50 Wheel Barrows for the said job. The wastes from the open points are cleared by safaikarmacharis and filled into tipper trucks. In the external areas of the city where the streets are broad, tricycles and Hopper Vehicles are used for door to door waste collection. There are about 1000 tri-cycles and 110 Hopper Vehicles for a door to door collection in the external areas. The waste collected using wheelbarrows and handcarts are disposed into nearest collector bins. The collection bins in the city are of 2 types- dumper bins of $3 \mathrm{~m}$ capacity and compactor bins of $1 \mathrm{~m}, 2.5 \mathrm{~m}$, and $5.5 \mathrm{~m}$. There are about 450 compactor bins and 110 dumper placer bins \& 132 Twin Dumper Placer Bins placed across the city. These bins are cleared using 18 dumper placers and 10 compactor vehicles. The collector bins are cleared every day. The waste collected by tricycles, Hopper Vehicles, and 4 wheeler vehicles is disposed of waste depots/compactor vehicle. The wastes from waste depots are cleared by tipper trucks (Fig 1). The waste from the waste depots is loaded to tipper trucks using front end loaders. The waste from open points are cleared by safaikarmacharis using wheelbarrows and disposed into nearest bins (Fig 2). Single bin dumper placers, compactors, and tipper trucks are used for secondary transportation of waste from intermediate storage points to disposal site. The waste carried by these vehicles is dumped at the landfill site located at Achan which is at a distance of $7 \mathrm{~km}$ from the city centre.

The dumping site land has an area of 64.5 acres / 516 Kanal and is owned by SMC. The waste received at the site is dumped into landfills and covered. The biomedical waste is handled separately by the generators.

\section{WASTE MANAGEMENT}

The average waste generation is about $0.4-0.6 \mathrm{~kg} /$ capita out of which $30-50 \%$ waste is bio-degradable. The SMC is working thoroughly in the field to ensure integrated and scientific solid waste management The waste from households and key bulk waste generators is collected by SMC employees daily, using a system of carts, hoppers, compactors, and trucks. All collected waste is transferred to the sanitary landfill site located at Achan . Resource recovery is done for about $25 \%$ of the total quantity of waste, but most of it is dumped into the scientifically designed landfill cells. The SMC is meanwhile actively looking to implement a longterm plan for Integrated Solid Waste Management, which would enable them to materialize the mission to develop Srinagar into a clean, hygienic and litter-free city. The SMC is also taking steps to sensitize the general public about Solid Waste Management through intensive Information Education and Communication (IEC) programs. Currently, 6 IEC Partners have been enlisted to help handhold the SMC to reach out to citizens in all wards. A Project Management Support Unit has also been commissioned to oversee the day-to-day activities of the IEC Partners and monitor their performance.

Daily about 450 metric tons of garbage is being generated within the Srinagar from hotels, restaurants, households poultry outlets which includes about 200 metric tons of Non-Vegetarian waste alone, daily about $40,000 \mathrm{~kg}$ of poultry waste is generated from poultry outlets only and if this highly nutritious and energy-rich edible offal is not managed properly each dog can have access to around a $\mathrm{kg}$ of such energy-rich diet from poultry offal only, the breeding efficiency and life span of stray dogs can increase and the population can touch the alarming levels (Fig 3). Srinagar Municipal Corporation has been constantly focusing on minimizing the availability of energy-rich garbage to stray dogs on the roads of the city and following effective and vital initiatives that have been launched. Special garbage collection vehicles for collection of poultry offal from most of the poultry outlets have been introduced. Special attention is being paid on the placement of dumper bins during the marriage ceremonies where huge quantity non-vegan food/ waste are being generated. Deployment of the additional fleet of special garbage collection light vehicles, compactors, Dumper placers, twin dumper vehicles, twin dumper bins, Tippers, Land dozers, Hoper vehicles, has resulted in reducing the availability of highly nutritious garbage waste to greater limits. A large number of twin coloured and smart garbage bins across the city have been introduced besides domestic garbage bins are also being distributed to households. Further mass awareness is created by issuing public advisories on dog bites and waste management. 


\section{Animal Birth Control and Anti Rabies programme: (ABC-AR Program)}

Animal Welfare Board of India in the year 2010 took up the execution of Animal Birth Control program for Stray dogs on a national scale through Local Animal Welfare Organizations, Municipalities, NGO's, etc. with two objectives:

i) To end the presence of stray dogs on roads and public places.

ii) To free India from the incidences of rabies by 2020 .

\section{Stray dog population management}

To address the issue of the growing dog population in the city, in addition to focusing on the proper garbage management Srinagar Municipal Corporation in collaboration with Animal Welfare Board of India and Sheri Kashmir University of Agriculture Science and Technology also initiated the process of establishing Animal Birth Control and anti-rabies centre (ABC-AR Centre) by signing a tripartite MOU on 11th August 2011. Land for the establishment of the proposed facility was offered by the veterinary college at Alusteng Shuhama , Land development, fencing of the facility and fifty dog Kennels were built by SMC and works on the project completed by May 2012. Initially, SKUAST - Veterinary faculty, being the implementing agency for carrying out the surgeries, offered their operation theatre for the conduct of surgeries and the program was launched on 1st May 2012. With the assistance of Animal Welfare Board of India, dog catchers were imparted special training at Jaipur too.

Considering the highly prolific nature of stray dogs with an average life span of about 2- 5 years and two breeding seasons a year, a multifold increase in their population can be expected if allowed to breed freely under the availability of energy-rich non-vegan edible waste - a female dog can add 10-15 pups to the population every year so fast track Sterilization of stray dogs along with effective garbage management is the only viable and effective tool to control the population. This is possible only if multiple ABC-AR centres are established across the city and sterilizations carried out at a massive scale for effective control of stray dogs. Till date around 2,000 sterilizations were conducted and also around 2,000 stray dogs were administered the anti-rabies vaccine.

Since the available infrastructure with Municipal Corporation at Shuhama - Alusteng is very less to cater only 10 to 15 sterilization a day and keeping in view the volume of sterilizations required, SMC has initiated to develop one more $\mathrm{ABC}$ centre.

Staff engaged with Animal Birth control Program (ABC-AR Program):-

\section{ABC-AR Project Tengpora under construction.}

Srinagar Municipal corporation has initiated the process of establishing one more Animal Birth Control and Anti Rabies centre at the available site at Tengpora at a project cost of around 1.4 crore rupees. In order to enhance the number of surgeries up to eighty surgeries a day, the work on the project is underway and it is expected that the creation of infrastructure shall be completed within a period of four to five months. With the establishment of ABC-AR Facility centre at Tengpora it shall have a separate operation theatre, 120 dogs kennel with staff accommodation as well. With its establishment, it is expected that $75 \%$ of the present population shall be sterilized after its establishment within a year to have a stable population in the city.

\section{People's and Commercial respondents' perception on waste management}

The majority, of the households, generated both the types of wastes $(79.06 \%, 77.08 \%)$. Regarding the generation of waste, the majority $(47.18 \%, 52.08 \%)$ disposed of their waste in containers. Most respondents $(75 \%$, $60.41 \%)$ didn't have large bins in the area. The bulk, $(50.62 \%, 58.33 \%)$ agreed about the regular disposal of waste. The dumping of waste alongside garbage bins was done by $(55.31 \%, 64.58 \%)$ the respondents (Table $2 \&$ Table 6$)$. The SMC $(92.50 \%, 93.75 \%)$ is the collection service was well-known by the respondents. The collection service was used by a few $(19.68 \%, 25 \%)$ of the respondents. Whether garbage bins are emptied, 
just $(23.43 \%, 39.58 \%$ ) few alleged (Table $3 \&$ Table 7 ). The most important feeding places of dogs were open garbage dumps $(99.68 \%, 100 \%)$, (Fig $4 \& 5$ ). About $(95.62 \%, 100 \%)$ of the respondents anticipated that garbage increases the stray dog population. Whilst $(36.56 \%, 33.33 \%)$ answered about bite during garbage dumping (Table $4 \&$ Table 8 ). All 100\% wanted a proper environment cleaning plus recommended control for dumps. Around $(97.81 \%, 100 \%)$ of the respondents believed there is no solid waste management in Srinagar (Table 5 \& Table 9).

\section{DISCUSSION}

Instead of its preventive probability, rabies prevails a public health dilemma of extreme attention. The condition is alarming in Srinagar where canine rabies has been critically overlooked. In Srinagar, the disease endurance is due to poverty and the rise of the stray dog population. The results show that respondents consider that open garbage dumps are a public health obstacle in the area (chiefly west zone) and commence to stray dogs proliferation. This could be because the area is congested and humans and dogs have frequent contact. This area is the downtown area of Srinagar where streets are populous every time. In this area, people usually throw food on the streets (Fig $6 \& 7$ ). The easy availability of food rendered by the scraps in the garbage not only enhances fertility in dogs, but scavenging makes dogs more prone to attack people. Dogs that get free food from the garbage dropped behind by bakeshops, abattoirs don't see people as providers of food and are major likely to attack them. Most garbage had a household origin and stray dogs were often attracted by fermentable wastes from cooking or lapsed foods. This finding is in agreement with ( Abedi et al., 2017 ; Raymond et al., 2015). A combined rabies control measure coupling dog sterilization, removal of factors that add to dog free-roaming and proliferation must be fulfilled. These combined measures can lead to rabies exclusion for the idea that in Srinagar, dogs are the chief rabies vectors. Therefore, awareness education should be organized, targeting people who are regularly accountable for the conveyor of garbage to dumps; that is, they are more likely to engage stray dogs scavenging for food nearby dumps.

Managing the municipal solid waste is a global confront. In a region like Jammu and Kashmir, the task is further daring given the novel topography and eco-friendly sensibilities. Even if The SMC is working meticulously in the field to guarantee incorporated and scientific solid waste management yet this method needs proper segregation of waste. Municipal authorities find all that an exigent job and that is the conjecture they want to lift all in vehicles and carry it to someplace where they plan to treat it, but this is very exigent because all the conveyed waste is in a blended form. This is mere re-location of garbage moderately than scientific processing.

Till date around 2,000 sterilizations were conducted and also around 2,000 stray dogs were administered the anti-rabies vaccine however this is too less in comparison with the total population of dogs and still, the ballot of dogs from the particular zones of Srinagar is deficient

These actions should be executed by the Srinagar government, which take the plan to boost the number of veterinary hubs all over.

In conclusion, open garbage dumps are a civic health barrier in the Srinagar district plus they instigate to stray dogs explosion. The simple accessibility of chow rendered through the leftovers in the waste does not merely boost fecundity in dogs, however, foraging makes dogs further prone to assail people. Dogs that obtain free food from the waste dropped near the bakeshops, abattoirs don't see citizens as a source of food plus are apt to assail them. The over-population of dogs is consequently formed as well as sustained by the abundance of possessions humans bestow with, so that it is, in prudence, a 'man-made' problem. Till date only around 2,000 sterilizations were conducted and also around 2,000 stray dogs were administered the anti-rabies vaccine however this is too less in comparison with the total population of dogs and still, the ballot of dogs from the particular zones of Srinagar is deficient.

\section{Conflicts of interest:}

None

\section{Ethics statement}


The study was approved by faculty of veterinary and animal husbandry Srinagar, Kashmir, India. Our appraisal consisted of semi-structured polls with each open and closed-ended question that was worn to grab the study's objectives.

\section{ACKNOWLEDGEMENT:}

Thankfulness can by no means be articulated in words. I am thankful to god, devoid of whom all else counts for zilch. There are numerous hands and hearts behind this effort.

I would like to utter my genuine admiration to my mentor Dr.Afzal Hoque Akand (Assistant professor of Division of Veterinary \& Animal Husbandry Extension), whose precious advice and insight I could not have completed without, I can't thank you enough. I am massively grateful to Dr. Abdul Hai Bhat for his direction, support and endurance for the conclusion of this study. To my advice-giving member Dr. Shabeer Ahmad Hamdani (Assistant professor of Division of Veterinary \& Animal Husbandry Extension), for his incessant support and guidance in every step of this journey, I am perpetually grateful. I also would like to extend my admiration to Dr. Syed Akram Hussain (Professor, Division of Veterinary Public Health), to Dr. Islamuddin Shiekh ( Professor, Division of Livestock Production \& Management) and Dr. Idrees Mehraj Allaie (Assistant professor of Division of Veterinary Parasitology) for their observant and support all through this journey. I would like to thank Dr. Mudasir Ali Rather, for his creative help all through the period of actualization of this thesis. I would like to thank SMC, for taking point from their hectic schedules and providing me all the records. I also want to thank my all respondents who found time to participate in my study. I bestow my whole critique to my family.

\section{Data availability statement}

The data is confidential.

\section{Funding;}

No funding was available

\section{REFERENCES}

Abedi, A. J., Khan, S., Mehnaz, S. \& Ansari, M. A. (2017). Open garbage dumps and knowledge of rabies among sanitary workers. International Journal of Community Medicine Public Health, 4 (5), 1722-1726. http://dx.doi.org/10.18203/2394-6040.ijcmph20171791

Ain, S. N., Khan, S. M. S., Azhar, M., Haq, S. \& Bashir, K. (2018). Epidemiological profile of animal bite victims attending an antirabies clinic in district Srinagar, Kashmir. Journal of Medical Sciences and ClinicalResearch, 6 , 599-603. https://dx.doi.org/10.18535/jmscr/v6i3.99

Chopra, D., Jauhari, N., Dhungana, H. \& Nasrah. (2017). Assessment of awareness about rabies and the animal bite among the staff nurses in a medical institute in Lucknow. International Journal of Community Medicine and Public Health, 4 (6), 2046-2051. http://www.ijcmph.com

Dabuma, T., Kabeta, T. \& Mengist, H, M. (2017). Assessment of basic knowledge, attitude and practice of community on rabies and retrospective Survey in and around Ambo Town, West Shoa Zone of Ethiopia. Journal of Medical Microbiology and Diagnosis, 6 , 2161-0703. 10.4172/2161-0703.1000263

Gebeyaw, S. \& Teshome, D. (2016). Study on community knowledge, attitude and practice of rabies in and around Dessie city. Journal of Veterinary Science and Animal Husbandry, 3 (1), 4. www.austinpublishinggroup.com

Ghosh, S., Chowdhury, S., Haider, N., Bhowmik, R. K., Rana, M. D., Marma, A. P., Hossain, M., Debnath, N.C.,.... Ahmed, B.N. (2016).Awareness of rabies and response to dog bites in a Bangladesh community. Veterinary Medicine and Science, 2 (3), 161-169. DOI: 10.1002/vms3.30

Ichhpujani, R.L., Chhabra, M., Mittal, V., Bhattacharya, D., Singh, J., \& Lal, S. (2006). Knowledge, attitude and practices about animal bites and rabies in general community. Journal of Communicable Diseases,38 , 
355-61. http:/www.researchgate.net

Kayali, U., Mindekem, R., Hulton, G., Nodurtamia, A.G \& Zinstag, J. (2006).Cost-description of a pilot parental vaccination campaign against rabies in N'Djamena, Chad.Tropical Medicine and International Health,11 , 1058-1065. doi:10.1111/j.1365-3156.2006.01663.x

Lone, K. S., Bilquees, S., Khan, M. S. \& Haq, I. U. (2014). Analysis of dog bites in Kashmir: An unprovoked threat to human population. National Journal of Community Medicine, 5 (1), 66 - 68. pISSN 0976 $3325 /$ eISSN 22296816

Raymond, T., Roland, M., Francoise, K., Francis, Z., Livo, E. \& Clovis, S. (2015). Do open garbage dumps play a role in canine rabies transmission in Biyem-Assi health district in Cameroon? Infection Ecology and Epidemiology,5 ,1-5.http://dx.doi.org/10.3402/iee.v5.26055

Sambo, M., Lembo, T., Cleaveland, S., Ferguson, H., Sikana, L., Simon, C., Urassa, H.,...Katie, H., (2014).Knowledge, attitudes and practices (KAP) about Rabies prevention and control: A community survey in Tanzania. Journal of Neglected Tropical Disease,8 (12), 3310. www.plosntds.org

The Greater Kashmir, (2013). Kashmir: 20 rabies deaths, 80,000 dogs bite cases in 5 years

\section{TABLES}

Table 1. Different zones and the wards of Srinagar district as per Srinagar Municipal Corporation

\begin{tabular}{|c|c|c|c|c|}
\hline Wards & $\begin{array}{l}\text { North zone }(9 \\
\text { wards) }\end{array}$ & $\begin{array}{l}\text { South zone ( } 9 \\
\text { wards) }\end{array}$ & $\begin{array}{l}\text { East zone ( } 8 \\
\text { wards) }\end{array}$ & $\begin{array}{l}\text { West zone } \\
\text { (8wards) }\end{array}$ \\
\hline 1 & $\begin{array}{l}\text { Tarbal, } \\
\text { JamiaMasjid,Kawdara }\end{array}$ & $\begin{array}{l}\text { Malroo, } \\
\text { Lawaypora }\end{array}$ & Harwan, Nishat & $\begin{array}{l}\text { SafaKadal, } \\
\text { IddGah }\end{array}$ \\
\hline 2 & $\begin{array}{l}\text { Zadibal,Madeen } \\
\text { Sahib }\end{array}$ & BeminaKhumaniChowl & $\begin{array}{l}\text { Dalgate, } \\
\text { Lalchowk }\end{array}$ & Palpora \\
\hline 3 & $\begin{array}{l}\text { Lal Bazaar, Umer } \\
\text { Colony }\end{array}$ & $\begin{array}{l}\text { AllochiBagh, } \\
\text { MagermalBagh }\end{array}$ & $\begin{array}{l}\text { Dud Dal, Locut } \\
\text { dal }\end{array}$ & $\begin{array}{l}\text { Nawab Bazaar, } \\
\text { Ali Kadal }\end{array}$ \\
\hline 4 & Hazratbal,Tailbal & $\begin{array}{l}\text { Rajbagh, } \\
\text { JawaharNagar,WazirB }\end{array}$ & $\begin{array}{l}\text { JogiLankar, } \\
\text { aggindashah Sahib }\end{array}$ & $\begin{array}{l}\text { Syed Ali Akbar, } \\
\text { Islam Yarbal }\end{array}$ \\
\hline 5 & $\begin{array}{l}\text { New Theed, } \\
\text { Alusteng }\end{array}$ & $\begin{array}{l}\text { Mahjoor Nagar, } \\
\text { Natipora, } \\
\text { Chanapora }\end{array}$ & $\begin{array}{l}\text { Ganpatyar, } \\
\text { Barbarshah }\end{array}$ & $\begin{array}{l}\text { Shaheed Gung, } \\
\text { Karan Nagar }\end{array}$ \\
\hline 6 & Zakoora & $\begin{array}{l}\text { BaghatBarzallua, } \\
\text { Rawalpora }\end{array}$ & \multicolumn{2}{|c|}{ BanaMohalla,Chinkralndoamathasari, } \\
\hline 7 & Ahmad Nagar & Humhama & $\begin{array}{l}\text { Akil Mir } \\
\text { Khanyar, Khaja } \\
\text { Bazar }\end{array}$ & $\begin{array}{l}\text { Bemina East, } \\
\text { BeminaWest }\end{array}$ \\
\hline 8 & Soura, Buchpora & $\begin{array}{l}\text { PanthaChowk, } \\
\text { Khanmoh }\end{array}$ & $\begin{array}{l}\text { Hasna Abad, } \\
\text { Makhdoom Sahib }\end{array}$ & $\begin{array}{l}\text { Parimpora, } \\
\text { Zainakote }\end{array}$ \\
\hline 9 & $\begin{array}{l}\text { Nowshahra, } \\
\text { Zoonimar }\end{array}$ & $\begin{array}{l}\text { S.D.colonyBatamaloo } \\
\text { Nundrash colony }\end{array}$ & & \\
\hline
\end{tabular}

Note: Highlighted wards indicate the sampled area

People's perception on waste management

Table 2. Distribution of respondents according to waste characteristics and disposal pattern 


\begin{tabular}{llll}
\hline Waste characteristics and disposal pattern & Waste characteristics and disposal pattern & Zones & Zones \\
\hline & & North & WEST \\
Question & & $\mathrm{n}$ & $\mathrm{n}$ \\
Waste collected & Response & 80 & 80 \\
& Biodegradable & $8(10)$ & $12(15)$ \\
& Non biodegradable & $11(13.75)$ & $8(10)$ \\
Place of disposal & All & $61(76.25)$ & $60(75)$ \\
& Nearby containers & $28(35)$ & $24(30)$ \\
& Open spaces & $43(53.75)$ & $28(35)$ \\
Any large bins in your area & Both & $9(11.25)$ & $28(35)$ \\
& Yes & $5(6.25)$ & $4(5)$ \\
Regular disposal & No & $75(93.75)$ & $76(95)$ \\
& Yes & $53(66.25)$ & $20(25)$ \\
You dump the waste alongside the roads & No & $27(33.75)$ & $60(75)$ \\
& Yes & $20(25)$ & $70(87.50$ \\
& No & $60(75)$ & $10(12.50$ \\
\hline
\end{tabular}

Figures in parenthesis indicate percentage, $n$ indicates sample size, " $N$ " total sample size

Table 3. Distribution of respondents about SMC service

\begin{tabular}{lll}
\hline SMC service & & Zones \\
\hline Questions & Response & North \\
& & $\mathrm{n}$ \\
& & 80 \\
Collection service available & SMC & $73(91.25)$ \\
& nothing & $7(8.75)$ \\
frequency of collection service & once a week & $15(18.75)$ \\
& More than a week & $65(81.25)$ \\
Garbage bins disposal & Once in two days & $5(6.25)$ \\
& Don't know & $75(93.75)$ \\
other options (Once in three days, Once a week) & other options (Once in three days, Once a week) & other options (Once \\
\hline
\end{tabular}

Figures in parenthesis indicate percentage, $n$ indicates sample size, " $N$ " total sample size

Table 4. Distribution of respondents according to the risk factors associated with stray dogs

\begin{tabular}{llllll}
\hline Question & Response & North & WEST & SOUTH & EAST \\
\hline & & $n$ & $n$ & $n$ & $n$ \\
Main feeding place of dogs & & 80 & 80 & 80 & 80 \\
& Open garbage dumps & $79(98.75)$ & $80(100)$ & $80(100)$ & $80(10$ \\
& Market houses & $1(1.25)$ & $0(0.00)$ & $0(0.00)$ & $0(0.00$ \\
Garbage increase the stray dog population & House & $0(0.00)$ & $0(0.00)$ & $0(0.00)$ & $0(0.00$ \\
& Yes & $77(96.25)$ & $76(95)$ & $76(95)$ & $77(96$ \\
People are bitten when they transport garbage to dumps & No & $3(3.75)$ & $4(5)$ & $4(5)$ & $3(3.75$ \\
& Yes & $43(53.75)$ & $32(40)$ & $18(22.50)$ & $24(30$ \\
& No & $37(46.25)$ & $48(60)$ & $62(77.50)$ & $56(70)$ \\
\hline
\end{tabular}


Figures in parenthesis indicate percentage, $n$ indicates sample size, " $N$ " total sample size

Table 5. Distribution of respondents according to waste management

\begin{tabular}{|c|c|c|c|}
\hline Questions & Zones & Zones & Zones \\
\hline & Response & North & West \\
\hline Do you want some recommended control for open garbage dumps & Yes & $80(100)$ & $80(100)$ \\
\hline other option(No) & other option(No) & other option(No) & other option(No \\
\hline Do you want a proper environment cleaning & Yes & $8(100)$ & $80(100)$ \\
\hline other option(No) & other option(No) & other option(No) & other option(No \\
\hline \multirow[t]{2}{*}{ Presence of any solid waste management in your city } & yes & $2(2.50)$ & $0(0.00)$ \\
\hline & no & $78(97.50)$ & $80(100)$ \\
\hline
\end{tabular}

Figures in parenthesis indicate percentage, $n$ indicates sample size, " $N$ " total sample size

Commercial respondents perception on waste management

Table 6. Distribution of Commercial respondent on waste characteristics/disposal pattern

\begin{tabular}{|c|c|c|c|c|}
\hline Waste characteristics/Disposal pattern & Waste characteristics/Disposal pattern & zones & zones & zones \\
\hline & & North & West & South \\
\hline & & $\mathrm{n}$ & $\mathrm{n}$ & $\mathrm{n}$ \\
\hline Questions & Response & 12 & 12 & 12 \\
\hline \multirow[t]{3}{*}{ Waste collected } & Biodegradable & $3(25)$ & $2(16.66)$ & $0(0.00)$ \\
\hline & Non biodegradable & $0(0.00)$ & $0(0.00)$ & $0(0.00)$ \\
\hline & both & $9(75)$ & $10(83.33)$ & $12(100)$ \\
\hline \multirow[t]{3}{*}{ Place of disposal } & Nearby containers & $10(83.33)$ & $3(25)$ & $8(66.66)$ \\
\hline & Open spaces & $0(0.00)$ & $6(50)$ & $0(0.00)$ \\
\hline & all & $2(16.66)$ & $3(25)$ & $4(33.33)$ \\
\hline \multirow[t]{2}{*}{ Any large bins in your area } & Yes & $0(0.00)$ & $1(8.33)$ & $12(100)$ \\
\hline & No & $12(100)$ & $11(91.66)$ & $0(0.00)$ \\
\hline \multirow[t]{2}{*}{ You have regular disposal of waste } & Yes & $8(66.66)$ & $2(1.66)$ & $12(100)$ \\
\hline & No & $4(33.33)$ & $10(83.33)$ & $0(0.00)$ \\
\hline \multirow[t]{2}{*}{ You dump the waste alongside the roads } & Yes & $8(66.66)$ & $8(66.66)$ & $7(58.33)$ \\
\hline & No & $4(33.33)$ & $4(33.33)$ & $5(41.66)$ \\
\hline
\end{tabular}

Figures in parenthesis indicate percentage,n indicates sample size, " $N$ " total sample size

Table 7. Distribution of commercial respondents about using SMC service

\begin{tabular}{lllllll}
\hline SMC service & Zones & Zones & Zones & Zones & Zones & Zones \\
\hline Question & Response & North & West & South & East & Pooled \\
& & $\mathrm{n}$ & $\mathrm{n}$ & $\mathrm{n}$ & $\mathrm{n}$ & $\mathrm{N}$ \\
& & 12 & 12 & 12 & 12 & 48 \\
$\begin{array}{l}\text { Collection } \\
\text { service } \\
\text { available }\end{array}$ & SMC & $12(100)$ & $11(91.66)$ & $12(100)$ & $10(83.33)$ & $45(93.75)$ \\
& & & & & \\
& nothing & $0(0.00)$ & $1(8.33)$ & $0(0.00)$ & $2(16.66)$ & $3(6.25)$
\end{tabular}




\begin{tabular}{|c|c|c|c|c|c|c|}
\hline SMC service & Zones & Zones & Zones & Zones & Zones & Zones \\
\hline \multirow{2}{*}{$\begin{array}{l}\text { Frequency } \\
\text { about the } \\
\text { collection } \\
\text { service }\end{array}$} & Once a week & $3(25)$ & $3(25)$ & $1(8.33)$ & $5(41.66)$ & $12(25)$ \\
\hline & $\begin{array}{l}\text { More than a } \\
\text { week }\end{array}$ & $9(75)$ & $9(75)$ & $11(91.66)$ & $7(58.33)$ & $36(75)$ \\
\hline \multirow[t]{2}{*}{$\begin{array}{l}\text { Garbage bin } \\
\text { disposal }\end{array}$} & $\begin{array}{l}\text { Once in two } \\
\text { days }\end{array}$ & $0(0.00)$ & $1(8.33)$ & $12(100)$ & $6(50)$ & $19(39.58)$ \\
\hline & (month) & $12(100)$ & 11(91.66) & $0(0.00)$ & $6(50)$ & $29(60.41)$ \\
\hline other & other & other & other & other & other & other \\
\hline options(once & options(once & options(once & options(once & options(once & options(once & options(once \\
\hline in three & in three & in three & in three & in three & in three & in three \\
\hline $\begin{array}{l}\text { days,once a } \\
\text { week) }\end{array}$ & $\begin{array}{l}\text { days,once a } \\
\text { week) }\end{array}$ & $\begin{array}{l}\text { days,once a } \\
\text { week) }\end{array}$ & $\begin{array}{l}\text { days,once a } \\
\text { week) }\end{array}$ & $\begin{array}{l}\text { days,once a } \\
\text { week) }\end{array}$ & $\begin{array}{l}\text { days,once a } \\
\text { week) }\end{array}$ & $\begin{array}{l}\text { days,once a } \\
\text { week) }\end{array}$ \\
\hline
\end{tabular}

Figures in parenthesis indicate percentage, $n$ indicates sample size, " $N$ " total sample size

Table 8. Perception of commercial respondents about the risk factors associated with stray dogs

\begin{tabular}{llll}
\hline Risk factors associated with stray dogs & Risk factors associated with stray dogs & zones & $\mathbf{z}$ \\
\hline Question & Response & North & n \\
& & $\mathbf{1 2}$ & $\mathbf{n}$ \\
& & $12(100)$ & 1 \\
Main feeding places of dogs & Open garbage dumps & Other options(No) & 1 \\
Other options(No) & Other options(No) & $12(100)$ & \\
Garbage increase the stray dog population & Yes & Other options(No) & ( \\
Other options(No) & Other options(No) & $6(50)$ & 3 \\
People are bitten when they transport garbage to dumps & Yes & $6(50)$ & 9 \\
& No & & \\
\hline
\end{tabular}

Figures in parenthesis indicate percentage, $n$ indicates sample size, " $N$ " total sample size

Table 9. Distribution of commercial respondents on waste management

\section{Waste management}

Question

Do you want some recommended control for open garbage dumps

other option(No)

Do you want a proper environment cleaning

other option(No)

Presence of any solid waste management in your city other option (no)
Response

Yes

other option(No)

Yes

other option(No)

Presence of any solid waste management in your city other option (no)

(Figures in parenthesis indicate percentage, $n$ indicates sample size, " $N$ " total sample size 


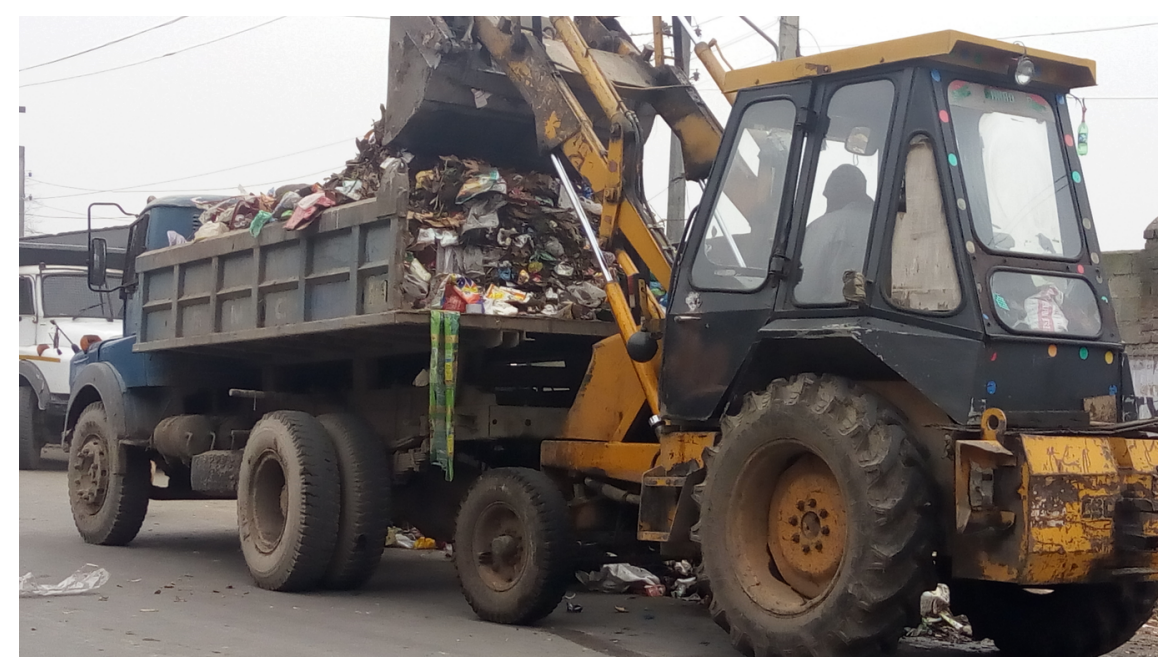




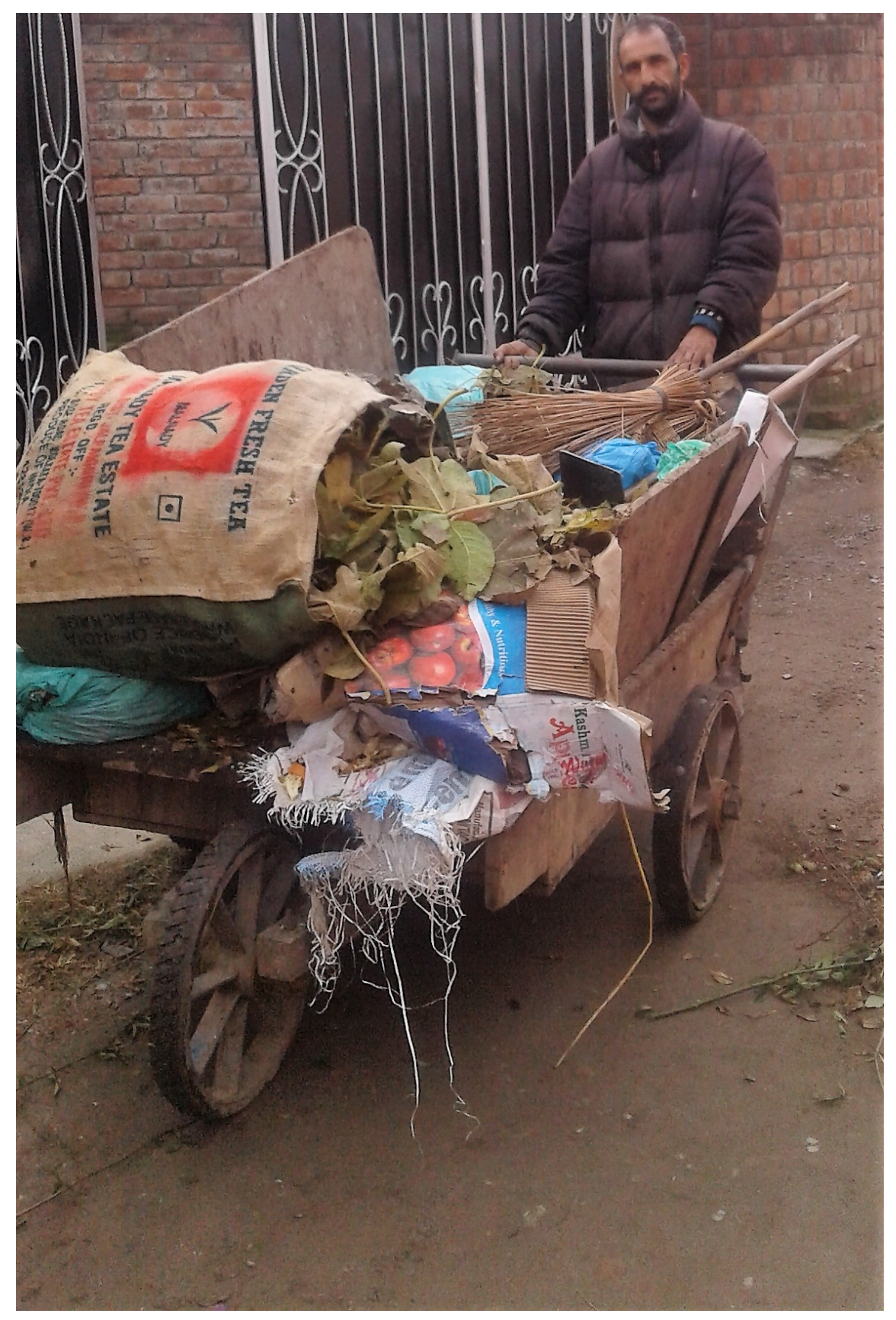



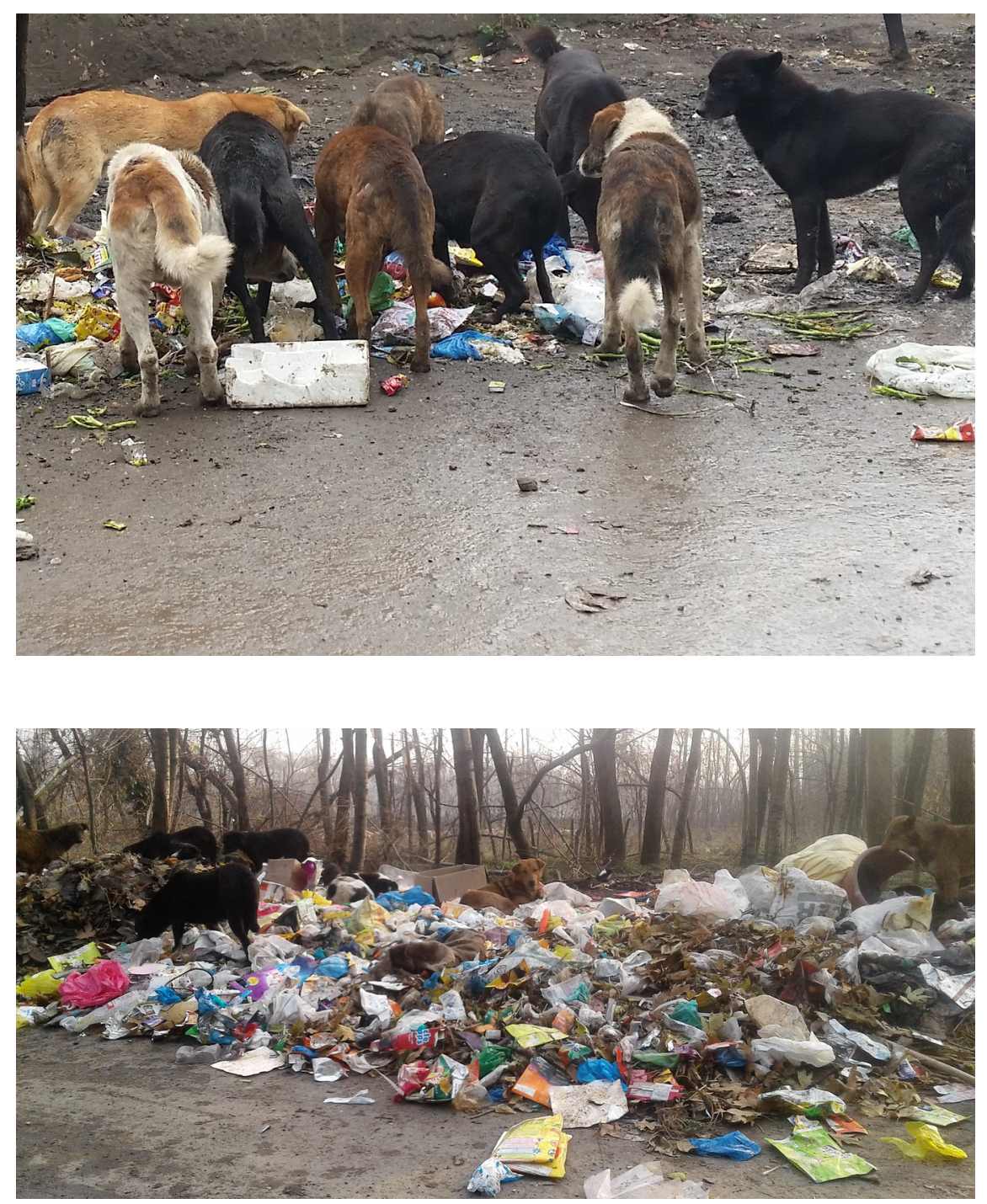

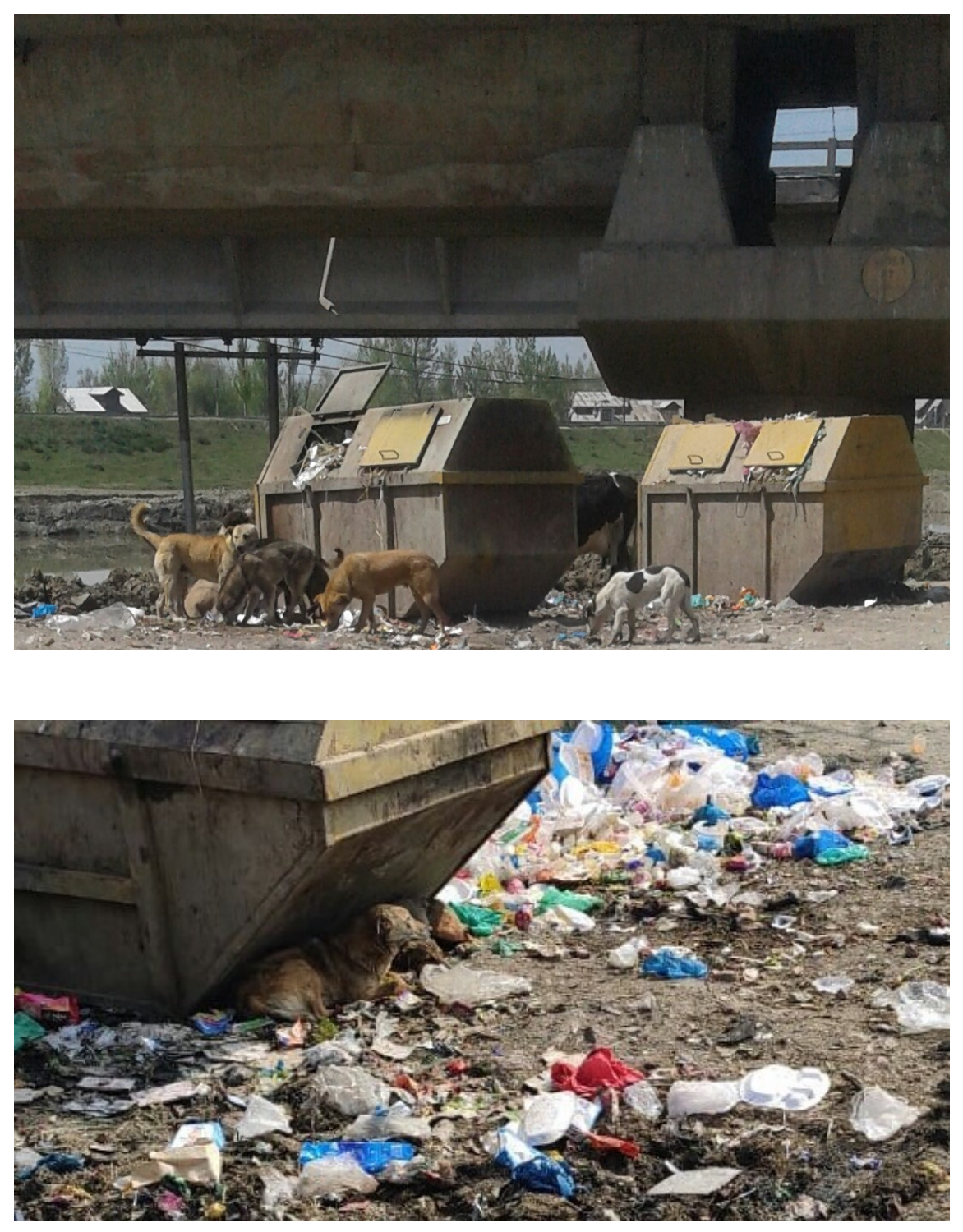


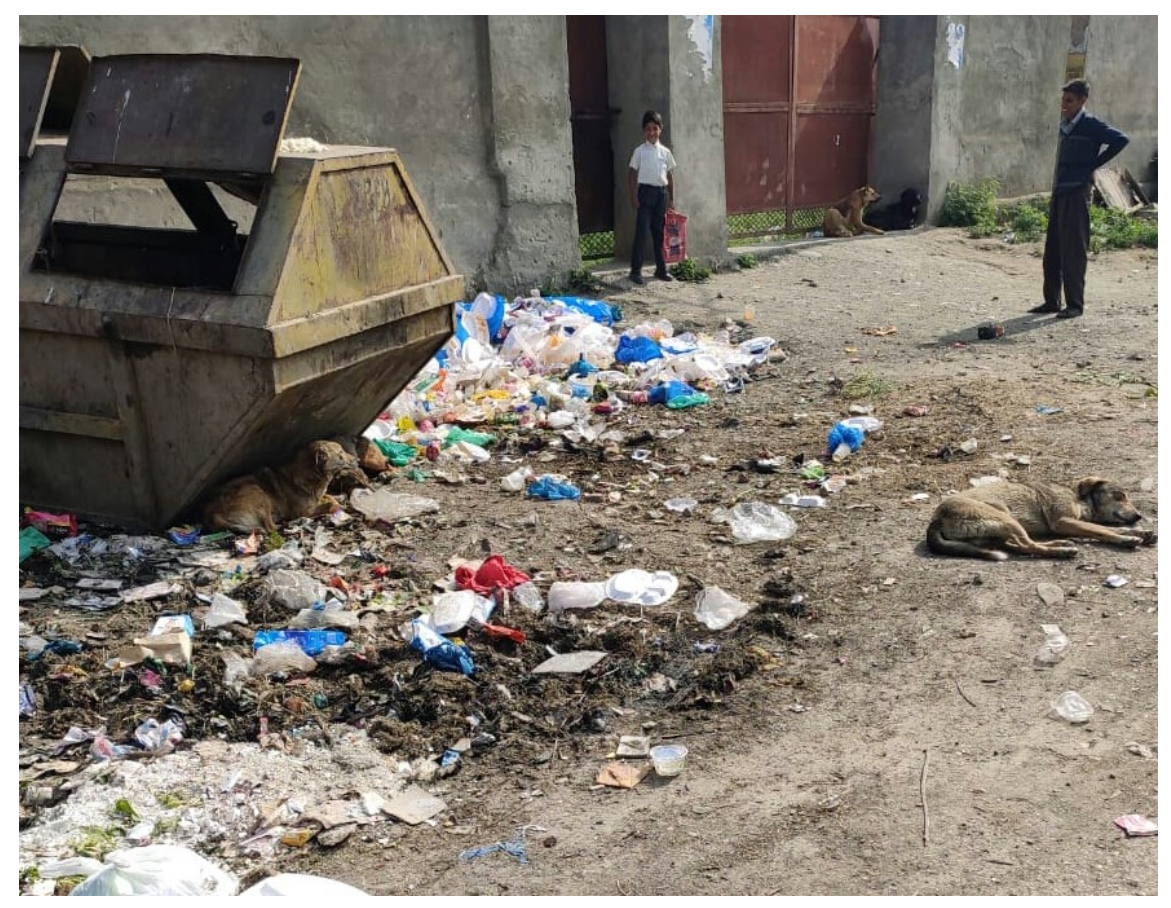

